\title{
Expression of Insulin-Like Growth Factor-I (IGF-I) in Aneurysmal Bone Cyst
}

Andreas Leithner, M.D., Susanna Lang, M.D., Reinhard Windhager, M.D., Katharina Leithner, M.D., Heidrun Karlic, Ph.D., Rainer Kotz, M.D., Oskar Arthur Haas, M.D.

Children's Cancer Research Institute (CCRI), St. Anna Children's Hospital (AL, OAH), Vienna; Clinical Institute of Clinical Pathology (SL) and Department of Orthopedic Surgery (RK), Vienna University Hospital, Vienna; Department of Orthopedic Surgery, Karl Franzens University (RW), Graz; Department of Vascular Biology and Thrombosis Research, Vienna University (KL), Vienna; and L. Boltzmann Institute for Leukemia Research and Hematology, Hanusch Hospital (HK), Vienna, Austria

The effects of insulin-like growth factor-I on bone tissue and its role in bone development have been extensively investigated, but there is little information on its role in the pathogenesis of aneurysmal bone cyst. Therefore, using the techniques of immunohistochemistry and in situ hybridization, the authors studied the expression of insulin-like growth factor-I in 19 specimens of aneurysmal bone cyst. Insulin-like growth factor-I or specific mRNA sequences encoding for insulin-like growth factor-I were detectable in all specimens tested and were mainly localized in multinucleate giant cells. In contrast, only insignificant levels of insulin-like growth factor-I expression were detectable in normal human bone tissue. Taken together with the previously reported role of insulin-like growth factor-I in the pathogenesis of giant cell tumor, the findings of this study suggest that insulin-like growth factor-I may play a role in the pathogenesis of aneurysmal bone cyst.

KEY WORDS: Aneurysmal bone cyst, Giant cell tumor, Immunohistochemistry, In situ hybridization, Insulin-like growth factor-I.

Mod Pathol 2001;14(11):1100-1104

The World Health Organization defines aneurysmal bone cyst $(\mathrm{ABC})$ as an expanding osteolytic lesion consisting of blood-filled spaces of variable size that are separated by connective tissue septa containing trabeculae of bone or osteoid tissue and osteoclast

Copyright (C) 2001 by The United States and Canadian Academy of Pathology, Inc.

VOL. 14, NO. 11, P. 1100, 2001 Printed in the U.S.A

Date of acceptance: June 21, 2001.

This work was partly supported by a grant of the University of Vienna (Förderungsstipendium).

Address reprint requests to: Reinhard Windhager, M.D., Department of Orthopedic Surgery, Karl Franzens University, Auenbruggerplatz 9, A - 8036 Graz, Austria; e-mail: reinhard.windhager@kfunigraz.ac.at; fax: 43-316-385-2957. giant cells (1). Although the incidence of $A B C$ is reported to be only 0.14 per 100.000 (2), since 1966, nearly 1000 articles have been published on this topic. The nature of $\mathrm{ABC}$, however, has still remained unclear and controversial (3-8), even leading Vicenzi to the conclusion that none of the present etiopathogenic theories is based on objective and convincing data (9). Most recently, Sciot et al. reported chromosomal aberrations in $\mathrm{ABC}$ suggesting that at least some ABCs are true neoplasms (10).

Insulin-like growth factor-I (IGF-I) is a polypeptide of about 7.5 $\mathrm{kDa}$ that has been shown to mediate the effects of growth hormone on skeletal growth and to have a variety of anabolic effects on cells of connective tissue origin (11-13). IGF-I has been implicated in the autocrine or paracrine regulation of cell proliferation and differentiation (14). The liver is the main production center, but other sources of IGFs are available for IGF-responsive tissues via autocrine or paracrine pathways $(11,12)$. In some neoplastic diseases, IGF-I is produced by the tumor itself (15).

Overexpression of IGF-I and its receptor has been observed in osteosarcoma and soft-tissue sarcoma $(16,17)$, astrocytoma and meningioma (18), giant cell tumor of bone (19), and other tumors $(15,20,21)$. Giant cell tumor of bone is sometimes strikingly similar to and occasionally indistinguishable from $A B C$ (22). Therefore, the recent findings on IGF-I expression in giant cell tumor of bone (19) have been the stimulus to investigate the expression of IGF-I in ABC.

\section{MATERIALS AND METHODS}

\section{Tissue Specimens}

Nineteen samples of ABC were obtained from 19 individuals at surgery. Tissue sections were fixed in $4.5 \%$ formaldehyde and were paraffin embedded according to standard procedure. The tissue samples were analyzed histologically. As only a limited 
number of tissue sections was assigned to this study, the samples were randomly divided between the two laboratories involved for either immunohistochemistry or RNA in situ hybridization.

Eight cases occurred in females and 11 in males, with a median age at presentation of 14 years (range, 7-46 years). Tumor sites and patient characteristics are indicated in Tables 1 and 2.

\section{Immunohistochemistry}

Nine formalin-fixed, paraffin-embedded tissue sections of $\mathrm{ABC}$ were deparaffinized with xylene, rehydrated with graded ethanols, and rinsed in water. Immunoreactivity was enhanced by autoclaving the slides for 25 minutes and cooling the slides in the closed autoclave for an additional 40 minutes. The sections were then incubated with primary murine monoclonal antibodies for IGF-I (Upstate Biotechnology, NY) diluted in Tris buffer, $\mathrm{pH} 7.5$, containing $2 \%$ horse serum, for 1 hour at room temperature. After washing with Tris buffer, the samples were incubated sequentially with biotinylated horse anti-mouse immunoglobulin diluted in horse serum for 30 minutes at room temperature, followed by avidin-biotin-complex-peroxidase (Vector Laboratories, Burlingame, CA). After rinsing in Tris buffer, peroxidase activity was detected with Fast Red (DAKO, Glostrup, Denmark). The tissue sections were counterstained with hematoxylin and covered with glycerol. All slides were evaluated by light microscopy. Monitoring of IGF-I- expression in each sample (negative, weak positive, or strong positive) was performed by comparing the intensity of staining. Normal human bone tissue, present in other sections, served as a reliable internal negative control, and human kidney tissue, as a positive control tissue.

\section{RNA In Situ Hybridization}

Eight-micrometer-thick formalin-fixed and paraffin-embedded tissue sections were deparaffinized using xylene and ethanol according to standard procedure and air dried at room temperature. The sections were permeabilized for in situ hybridization by pepsin digestion with $2.5 \mathrm{mg} / \mathrm{mL}$ pepsin (Kreatech Diagnostics, Amsterdam, The Netherlands) in $0.1 \mathrm{M} \mathrm{HCl}$ for 30 minutes at $37^{\circ} \mathrm{C}$. Slides were dehydrated with ethanol. For each slide, $50 \mathrm{ng}$ of probes (366-bp-long digoxigenin-labeled cDNA fragments corresponding to human mRNA for IGFIa, positions 88-434) diluted in 20- $\mu$ l hybridization solution (Hybrisol IV, Oncor, Gaithersburg, MD) were applied. Slides were covered with a glass coverslip and sealed with rubber cement.

In order to ensure perfect permeabilization and denaturation of probes and targets, slides were placed in a metal box and heated for 5 minutes in an $80^{\circ} \mathrm{C}$ waterbath and then incubated overnight at $37^{\circ} \mathrm{C}$. After hybridization, slides were washed three times in $50 \%$ formamide buffer for 10 minutes and two times in $2 \times$ SCC $(2 \times$ SCC: $0.03 \mathrm{~m}$ sodium citrate

TABLE 1. Patient Characteristics and Results of Immunostaining for Insulin-Like Growth Factor-I in Aneurysmal Bone Cyst

\begin{tabular}{|c|c|c|c|c|c|c|}
\hline \multirow{2}{*}{ Patient No. } & \multirow{2}{*}{ Gender } & \multirow{2}{*}{ Age (y) } & \multirow{2}{*}{ Location } & \multirow{2}{*}{ Diagnosis } & \multicolumn{2}{|c|}{ Immunostaining } \\
\hline & & & & & Stroma & Giant Cells \\
\hline 1 & M & 15 & Tibia & $\mathrm{ABC}$ & ++ & + \\
\hline 2 & M & 10 & Femur & $\mathrm{ABC}$ & ++ & ++ \\
\hline 3 & M & 7 & Femur & $\mathrm{ABC}$ & ++ & ++ \\
\hline 4 & M & 21 & Sacrum & $\mathrm{ABC}$ & ++ & ++ \\
\hline 5 & $\mathrm{~F}$ & 22 & Rib & $\mathrm{ABC}$ & ++ & + \\
\hline 6 & M & 13 & Fibula & $\mathrm{ABC}$ & ++ & + \\
\hline 7 & $\mathrm{~F}$ & 14 & Ischium & $\mathrm{ABC}$ & ++ & ++ \\
\hline 8 & $\mathrm{~F}$ & 19 & Pubic & ABC solid & - & ++ \\
\hline 9 & M & 46 & Ilium & ABC solid & ++ & + \\
\hline
\end{tabular}

+, weak expression; ++, strong expression; -, no expression detected.

TABLE 2. Patient Characteristics and Results of In Situ Hybridization with Antisense Oligonucleotides to Insulin-Like Growth Factor-I mRNA in Aneurysmal Bone Cyst

\begin{tabular}{ccclll}
\hline Patient No. & Gender & Age $(\mathrm{y})$ & Location & Diagnosis & Detection Method \\
\hline 10 & F & 11 & Femur & ABC & Fluorescent \\
11 & M & 12 & Femur & ABC & Fluorescent \\
12 & F & 10 & Lumbar spine & ABC & Fluorescent \\
13 & F & 32 & Radius & ABC & Fluorescent \\
14 & M & 11 & Sacrum & ABC & Peroxidase \\
15 & M & 7 & Humerus & ABC & Peroxidase \\
16 & F & 16 & Femur & ABC & Alkaline phosphatase \\
17 & F & 17 & Fibula & ABC solid & Alkaline phosphatase \\
18 & M & 32 & Fibula & ABC & Alkaline phosphatase \\
19 & M & 12 & Femur & ++ \\
\hline
\end{tabular}

+ , weak expression; ++ , strong expression. 

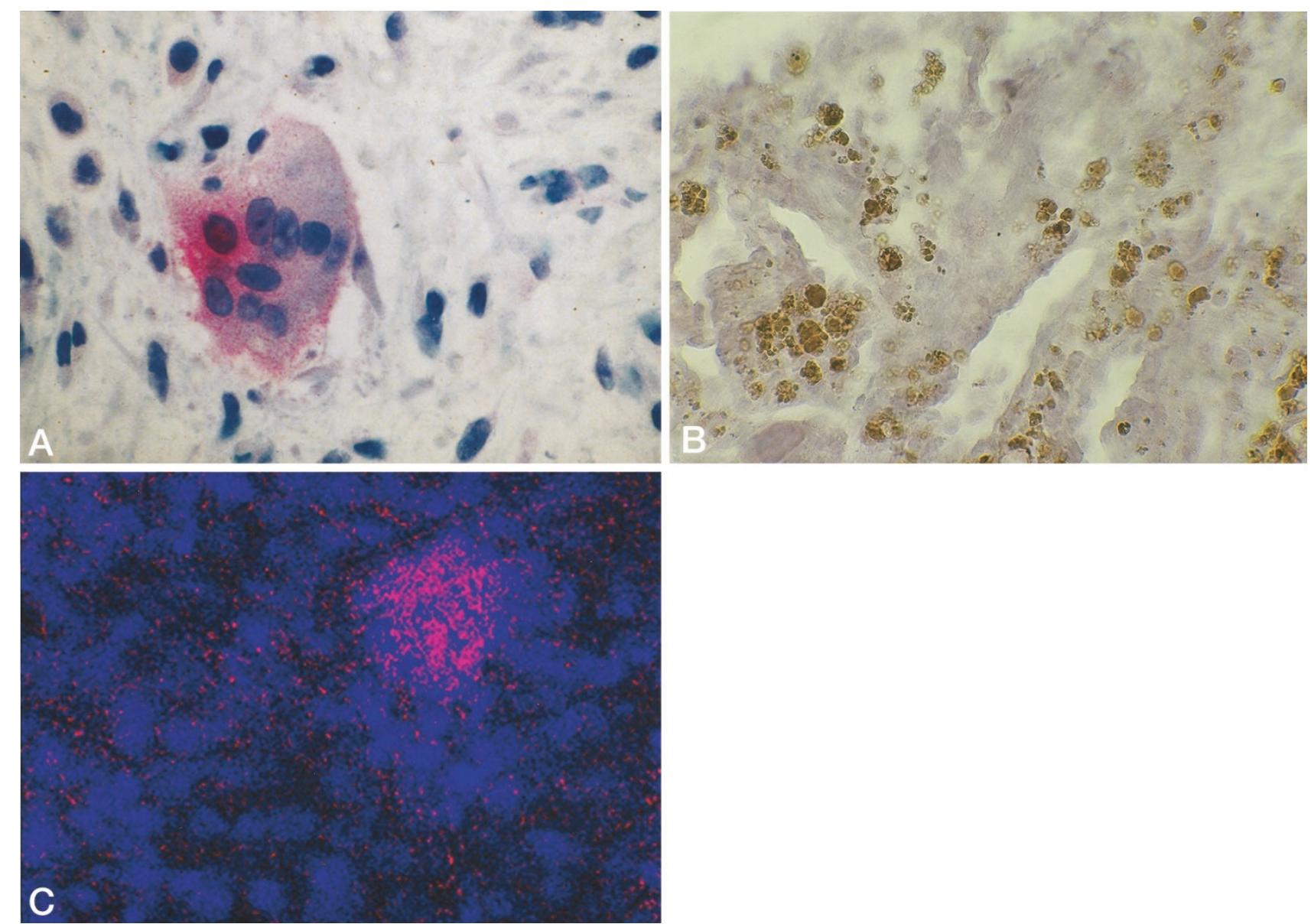

FIGURE 1. A, immunohistochemical analysis of IGF-I in ABC (Patient 9). A multinucleate giant cell is strongly positive for IGF-I (200×). B, in situ hybridization with digoxigenin-labeled antisense oligonucleotides to IGF-I mRNA (Patient 17). Probes were detected with anti-digoxigenin antibodies conjugated to alkaline phosphatase. A multinucleate giant cell (on the left) and mononuclear stromal cells exhibit a strong signal (500 $\times$ ). C, fluorescent detection of digoxigenin-labeled IGF-I mRNA (Patient 10). Probes were detected with anti-digoxigenin antibodies conjugated to rhodamine. Cell nuclei are stained blue. The strong signal corresponds to a multinucleate giant cell $(500 \times)$.

$+0.3 \mathrm{M}$ sodium chloride). After washing with phosphate buffered saline (PBS; three times, each for 10 minutes), riboprobes were detected by using fluorescent detection in four cases and colorimetric detection methods in six cases.

For fluorescent detection, slides were incubated with anti-digoxigenin antibodies conjugated to rhodamine (Roche Diagnostics, Mannheim, Germany) diluted 1:10 in PBS plus 1\% blocking solution (Roche) for 30 minutes at $37^{\circ} \mathrm{C}$. Afterwards, slides were washed with PBS for 2 minutes and rinsed with water. Sections were incubated with $2-\mu \mathrm{g} / \mathrm{mL}$ DAPI (Sigma, St. Louis, MO) in McIlvaine's buffer $(0.1 \mathrm{~m}$ citric acid monohydrate $+0.2 \mathrm{~m}$ disodium hydrogen phosphate) for 20 minutes, mounted with $50 \%$ glycerol in PBS, and coverslipped.

For colorimetric detection, three sections were incubated with anti-digoxigenin antibodies conjugated to alkaline peroxidase (Roche) diluted 1:10 in PBS plus $1 \%$ blocking solution (Roche), and another three sections were incubated with anti-digoxigenin antibodies conjugated to horseradish peroxidase (In Situ Hybridization and Detection Kit, Kreatech) for 30 minutes at $37^{\circ} \mathrm{C}$. After washing with PBS and alkaline detection buffer (Roche), sections were incubated with NBT/BCIP (Roche) for detection of alkaline phosphatase. Horseradish peroxidase was detected by application of AEC solution (Kreatech) for up to 15 minutes at $37^{\circ} \mathrm{C}$. Then slides were washed with water and air dried. Sections were counterstained with methyl green-pyronine or giemsa, mounted with $50 \%$ glycerol in PBS, and coverslipped.

As a negative control for all three detection methods, sections incubated with plain hybridization solution, and smears of blood from healthy donors were used. Blood smears containing 50\% B-cell blasts served as a positive control.

\section{RESULTS}

\section{Detection of IGF-I in ABC by Immunohistochemistry}

Immunoreactivity for IGF-I was found in all nine specimens of ABC tested (No. 1-9). No difference in the level of IGF-I was found between seven cystic 
ABCs (No. 1-7) and two solid ABCs (No. 8 and 9). Mononuclear stromal cells were strongly positive for IGF-I in eight of nine samples. Multinucleate giant cells were strongly positive in five of nine samples, and a weak expression was found in four of nine samples (Fig. 1A). In contrast, in none of the specimens did any normal human bone tissue show significant immunostaining for IGF-I.

\section{In Situ Hybridization}

To determine whether elevated levels of IGF-I in $\mathrm{ABC}$, as revealed by immunohistochemistry, occur due to overexpression of IGF-I in ABC or due to increased binding of exogenous IGF-I, in situ hybridization was performed on ten specimens of $\mathrm{ABC}$ with an antisense IGF-Ia digoxigenin-labeled riboprobe. Three different detection methods were applied. All specimens tested showed positive staining for IGF-I mRNA. Four of ten samples (No. 13-15 and 19) displayed weak staining; in six of ten samples (nos. 10-12 and 16-18), staining for IGF-I mRNA was strong. In all specimens tested, IGF-I transcripts were located in multinucleate giant cells but also in mononuclear stromal cells (Fig. $1 \mathrm{~B}+1 \mathrm{C}$ ). In contrast, staining was absent in the negative controls, thus excluding false positive results as obtained by autoimmunofluorescence or unspecific enzymatic activity that might have resulted from, for instance, hemosiderin.

\section{DISCUSSION}

The results of this study demonstrate that IGF-I is overexpressed in $\mathrm{ABC}$. Together with reports on the growth-promoting activity of IGF-I (13) and on the expression of IGF-I in many bone tumors $(16,17$, 19), including giant cell tumors (19), the results of this study indicate that locally produced IGF-I might play a role in the development and growth and of ABC. Furthermore, multinucleate giant cells, which have been shown to synthesize IGF-I in giant cell tumors (19), might be of importance in that process.

An important differential diagnosis of $\mathrm{ABC}$ is giant cell tumor of bone (22). Microscopically, it is sometimes impossible to tell the two apart (22). Comparing the findings of IGF-I-expression in ABC with the previously reported findings in giant cell tumor (19), there seems to be no major difference in IGF-I-overexpression. Therefore, this aspect is not helpful for a practical diagnostic application.

As IGF-I is directly involved in fracture healing (23), the history of all patients was reviewed with special attention to a possible pathologic fracture caused by the osteolytic defect. Four of the patients (No. 11, 13, 15, and 19) had presented with this complication. However, in situ hybridization showed no difference between nonfractured and fractured ABCs.

Several conditions with elevated IGF-I serum levels, such as pregnancy $(24,25)$, trauma $(26)$, and the adrenogenital syndrome (27), display a coincidence with ABC (28-38). Furthermore, ABC has a peak incidence in the first two decades (2), in which IGF-I serum levels are reported to be high (39-41). Also, for Van Buchem's disease, which is similar to acromegaly $(42,43)$, a disorder with elevated IGF-I serum levels $(44,45)$, a coincidence with $\mathrm{ABC}$ has been described (37). The involvement of IGF-I in the pathogenesis of $\mathrm{ABC}$ might explain the coincidence of these conditions with $\mathrm{ABC}$.

In conclusion, the data presented in this study demonstrate that IGF-I is overexpressed in ABC, indicating a possible role of the IGF-I-system in the pathogenesis and growth of this lesion. Other curious phenomena like the five reported familial cases of $\mathrm{ABC}(9,46-49)$ and the several congenital cases (50-52) could be better understood by searching for an underlying, possibly genetic defect in the growth hormone/IGF-I system. However, the exact mechanisms of the growth of $\mathrm{ABC}$, the role of multinucleate giant cells, and the true nature of this entity remain unclear.

\section{REFERENCES}

1. Schajowicz F. Histological typing of bone tumors. In: World Health Organization, editor. International histological classification of tumors. 2nd ed. Berlin: Springer; 1993. p. 37.

2. Leithner A, Windhager R, Lang S, Haas OA, Kainberger F, Kotz R. Aneurysmal bone cyst: a population based epidemiologic study and literature review. Clin Orthop 1999;363: $176-9$.

3. Ruiter DJ, van Rijssel TG, van der Velde EA. Aneurysmal bone cysts: a clinicopathological study of 105 cases. Cancer 1977; 39:2231-9.

4. Alles JU, Schulz A. Immunocytochemical markers (endothelial and histiocytic) and ultrastructure of primary aneurysmal bone cysts. Hum Pathol 1986;17:39-45.

5. Martinez V, Sissons HA. Aneurysmal bone cyst: a review of 123 cases including primary lesions and those secondary to other bone pathology. Cancer 1988;61:2291-304.

6. Kransdorf MJ, Sweet DE. Aneurysmal bone cyst: concept, controversy, clinical presentation, and imaging. Am J Roentgenol 1995;164:573-80.

7. Windhager R, Lang S, Kainberger F. Die aneurysmatische Knochenzyste. Orthopade 1995;24:57-64.

8. Capanna R, Campanacci DA, Manfrini M. Unicameral and aneurysmal bone cysts. Orthop Clin North Am 1996;27:60514

9. Vicenzi G. Familial incidence in two cases of aneurysmal bone cyst. Ital J Orthop Traumatol 1981;7:251-3.

10. Sciot R, Dorfman H, Brys P, Dal Cin P, De W, I, Fletcher CD, Jonson K, Mandahl N, Mertens F, Mitelman F, Rosai J, Rydholm A, Samson I, Tallini G, Van den BH, Vanni R, Willen H. Cytogenetic-morphologic correlations in aneurysmal bone cyst, giant cell tumor of bone and combined lesions. A report from the CHAMP study group. Mod Pathol 2000;13:1206-10.

11. D'Ercole AJ, Stiles AD, Underwood LE. Tissue concentrations of somatomedin C: further evidence for multiple sites of 
synthesis and paracrine or autocrine mechanisms of action. Proc Natl Acad Sci U S A 1984;81:935-9.

12. Mathews LS, Norstedt G, Palmiter RD. Regulation of insulinlike growth factor I gene expression by growth hormone. Proc Natl Acad Sci U S A 1986;83:9343-7.

13. Rodan SB, Wesolowski G, Thomas K, Rodan GA. Growth stimulation of rat calvaria osteoblastic cells by acidic fibroblast growth factor. Endocrinology 1987;121:1917-23.

14. Holly JMP, Wass JAH. Insulin-like growth factors; autocrine, paracrine or endocrine? New perspectives of the somatomedin hypothesis in the light of recent developments. J Endocrinol 1989;122:611-8.

15. Daughaday WH. The possible autocrine/paracrine and endocrine roles of insulin-like growth factors of human tumors. Endocrinology 1990;127:1-4.

16. Pinski J, Schally AV, Groot K, Halmos G, Szepeshazi K, Zarandi $\mathrm{M}$, Armatis $\mathrm{P}$. Inhibition of growth of human osteosarcomas by antagonists of growth hormone-releasing hormone. J Natl Cancer Inst 1995;87:1787-94.

17. Sekyi-Otu A, Bell RS, Ohashi C, Pollak M, Andrulis IL Insulin-like growth factor 1 (IGF-1) receptors, IGF-1, and IGF-2 are expressed in primary human sarcomas. Cancer Res 1995;55:129-34.

18. Antoniades HN, Galanopoulos T, Neville-Golden J, Maxwell M. Expression of insulin-like growth factors I and II and their receptor mRNAs in primary human astrocytomas and meningiomas; in vivo studies using in situ hybridization and immunocytochemistry. Int J Cancer 1992;50:215-22.

19. Middleton J, Arnott N, Walsh S, Beresford J. The expression of mRNA for insulin-like growth factors and their receptor in giant cell tumors of human bone. Clin Orthop 1996;322:224-31.

20. Williams DW, Williams ED, Wynford TD. Evidence for autocrine production of IGF-1 in human thyroid adenomas. Mol Cell Endocrinol 1989;61:139-43.

21. Yee D, Morales FR, Hamilton TC, Von Hoff DD. Expression of insulin-like growth factor I, its binding proteins, and its receptor in ovarian cancer. Cancer Res 1991;51:5107-12.

22. Vergel De Dios AM, Bond JR, Shives TC, McLeod RA, Unni KK. Aneurysmal bone cyst: a clinicopathologic study of 238 cases. Cancer 1992;69:2921-31.

23. Andrew JG, Hoyland J, Freemont AJ, Marsh D. Insulinlike growth factor gene expression in human fracture callus. Calcif Tissue Int 1993;53:97-102.

24. Hizuka N, Takano K, Asakawa K, Sukegawa I, Fukuda I, Demura H, Iwashita M, Adachi T, Shizume K. Measurement of free form of insulin-like growth factor I in human plasma. Growth Regul 1991;1:51-5.

25. Hasegawa T, Hasegawa Y, Takada M, Tsuchiya Y. The free form of insulin-like growth factor I increases in circulation during normal human pregnancy. J Clin Endocrinol Metab 1995;80:3284-6.

26. Karachaliou FH, Stamogiannou L, Maravelias K, Bartsocas CS, Koutselinis A. Long bone fracture healing: IGF-I concentrations and specific binding to erythrocytes. J Pediatr Endocrinol Metab 1996;9:491-5.

27. Keenan BS, Richards GE, Mercado M, Dallas JS, Eakman GD, Baumann G. Androgen regulation of growth hormone binding protein. Metabolism 1996;45:1521-6.

28. Baker HL, Papsidero MJ, Batsakis JG, Krause CJ. Aneurysmal bone cyst of the ethmoid. Head Neck Surg 1982;5:177-80.

29. Wachter W, Adler CP. Aneurysmale knochenzyste des os temporale. Laryngol Rhinol Otol (Stuttg) 1984;63:622-5.

30. Issa AA, Amr SS, Swaiss AM. Aneurysmal bone cyst of the ilium associated with pregnancy. Eur J Obstet Gynecol Reprod Biol 1986;23:243-8.

31. Cataltepe O, Inci S, Ozcan OE, Saglam S, Erbengi A. Aneurysmal bone cyst of the frontal bone. Surg Neurol 1990;33:391-4.

32. Onuigbo MA. Fracture of bone with an aneurysmal bone cyst during lactation. Cent Afr J Med 1990;36:84-7.
33. Levy WM, Miller AS, Bonakdarpour A, Aegerter E. Aneurysmal bone cyst secondary to other osseous lesions. Report of 57 cases. Am J Clin Pathol 1975;63:1-8.

34. Kushner DC, Vance Z, Kirkpatrick JA Jr. Case report 103: post-traumatic aneurysmal bone cyst affecting third and fourth ribs. Skeletal Radiol 1979;4:240-3.

35. Dabezies EJ, D'Ambrosia RD, Chuinard RG, Ferguson AB Jr. Aneurysmal bone cyst after fracture: a report of three cases. J Bone Joint Surg Am 1982;64:617-21.

36. Ratcliffe PJ, Grimer RJ. Aneurysmal bone cyst arising after tibial fracture: a case report. J Bone Joint Surg Am 1993;75: 1225-7.

37. Veth RP, Nielsen HK, Schraffordt Koops H, Oosten HR, Molenaar WM. Van Buchem's disease and aneurysmal bone cyst: a case history. Arch Orthop Trauma Surg 1985;104: 65-8.

38. Burman MS, Gardner RC, Lauter CB. Aggressive giant cell tumor in a young female with congenital adrenal virilism (adrenogenital syndrome): report of an unusual association of a bone neoplasm with an endocrine disorder. Cancer 1970;25:1174-7.

39. Blum WF, Ranke MB, Kietzmann K, Gauggel E, Zeisel HJ, Bierich JR. A specific radioimmunoassay for the growth hormone (GH)-dependent somatomedin-binding protein: its use for diagnosis of GH deficiency. J Clin Endocrinol Metab 1990;70:1292-8.

40. Falorni A, Bini V, Cabiati G, Papi F, Arzano S, Celi F, Sanasi M. Serum levels of type I procollagen C-terminal propeptide, insulin-like growth factor-I (IGF-I), and IGF binding protein-3 in obese children and adolescents: relationship to gender, pubertal development, growth, insulin, and nutritional status. Metabolism 1997;46:862-71.

41. Juul A, Bang P, Hertel NT, Main K, Dalgaard P, Jorgensen K, Muller J, Hall K, Skakkebaek NE. Serum insulin-like growth factor-I in 1030 healthy children, adolescents, and adults: relation to age, sex, stage of puberty, testicular size, and body mass index. J Clin Endocrinol Metab 1994;78:744-52.

42. Van Buchem FSP, Hadders HN, Hansen JF, Woldring MG. Hyperostosis corticalis generalisata: report of seven cases. Am J Med 1962;33:387-97.

43. Van Buchem FSP. Hyperostosis corticalis generalisata: eight new cases. Acta Med Scand 1971;189:257-67.

44. Melmed S. Acromegaly. Metabolism 1996;45:51-2.

45. Jansson JO, Svensson J, Bengtsson BA, Frohman LA, Ahlman $\mathrm{H}$, Wangberg B, Nilsson O, Nilsson M. Acromegaly and Cushing's syndrome due to ectopic production of GHRH and ACTH by a thymic carcinoid tumour: in vitro responses to GHRH and GHRP-6. Clin Endocrinol Oxf 1998;48:243-50.

46. Greco F, De Palma L, Coletti V. Un caso familiare di cisti ossea aneurismatica. Arch Putti Chir Organi Mov 1983;33: 441-6.

47. Power RA, Robbins PD, Wood DJ. Aneurysmal bone cyst in monozygotic twins: a case report. J Bone Joint Surg Br 1996; 78:323-4.

48. Leithner A, Windhager R, Kainberger F, Lang S. A case of aneurysmal bone cyst in father and son. Eur J Radiol 1998; 29:28-30.

49. DiCaprio MR, Murphy MJ, Camp RL. Aneurysmal bone cyst of the spine with familial incidence. Spine 2000;25:1589-92.

50. Ginsburg LD. Congenital aneurysmal bone cyst: case report with comments on the role of trauma in the pathogenesis. Radiology 1974;110:175-6.

51. Lamb CR, Schelling SH. Congenital aneurysmal bone cyst in the mandible of a foal. Equine Vet J 1989;21:130-2.

52. Lackmann GM, Isenberg H, Tollner U, Draf W, Bohm HJ. Aneurysmatische Knochenzyste des Felsenbeins: seltene Ursache einer rekurrierenden bakteriellen Meningitis. Monatsschr Kinderheilkd 1993;141:855-9. 